\title{
POSSESSED BY A SLAVE, NOT SLAVERY
}

\begin{abstract}
What I liked in anthropology was its inexhaustible faculty of negation, its relentless definition of man, as though he were no better than God, in terms of what he is not
\end{abstract}

(Beckett 1958: 35).

\begin{abstract}
The present paper is divided into three large steps around the themes of spirit possession and the historical imagination of slavery in Cuba. These three steps reflect both ethnographic dimensions of these themes and broader theoretical approaches towards them. The last step, 'apomimesis', is the one proposed by the author, not by way of replacement but displacement. The first step, 'formulaic' historical imagination, covers the ground of a direct expression of slavery as historical trauma through spirit possession. The second step, 'mimesis', displaces the first by adding into it the possibility of reversal, of empowerment, the slave becoming an anti-slave. The third creates another simultaneous condition. Through the negative dialectics of apomimesis the non-slave emerges.
\end{abstract}

Keywords: Afro-Cuban religion, divination, historical imagination, mimesis, negative dialectics, slavery, spirit possession

\section{CAPTIVE IMAGERY OF CAPTURED BODIES}

We are in the relatively ample living-room of a run-down, colonial-style house in innercity Havana. It is crammed with people of all ages, sizes, shapes, colors, and styles. The heavy tropical Cuban climate is accentuated by the humidity emanating from the collective movement, respiration, and perspiration of the bodies of those present. Amid this human ceremonial conservatory stands Pablo. The drumming has just abruptly stopped, and the fingers of the musicians are still lingering, sweaty and trembling, over the stretched goatskins of the rustic percussion. Pablo, too, after having danced to the sound of the drums, has come to a halt. He exclaims, 'Good evening my people!' as if he has just arrived at the event. The crowd, correspondingly, answers in one voice: 'Good evening Ta' José!' For what is to follow, Pablo will act and be recognized as $\mathrm{Ta}$ ' José, the spirit of an African slave who lived and suffered an untimely death as a forced laborer in the sugarcane fields of colonial Cuba. As such, he has indeed just arrived (once more!).

The first transformation I notice about his transition from Pablo to Ta' José is verbal. The tone of his voice has become harsher and more abrupt, and the accent is harder to understand to the untrained ear. There is also a change in the body posture. When he is not talking, he 
looks at the floor and his gestures are slower; he also exhibits difficulty in walking.

After greeting his people Ta' José turns his attention towards specific individuals. $\mathrm{He}$ turns to one elderly woman and tells her: 'Your grandson is a thief and a liar. You have to put him on the right track; if not, he will end up in jail'. To another, a middle-aged man, he says somewhat enigmatically: 'What you are looking for is buried in your uncle's backyard, at the roots of a tall tree'. To a young woman: 'You suffer from health issues in your intestines, but the origin is not medical but witchcraft [brujería]. Ta' José gives advice to many more in the room. As he limps around, he is gasping for breath and sweating excessively, even though his movement is intermittent and sluggish. After two full hours of person-to-person advice and regular consumption of rum and cigars, he asks for certain ingredients to be placed as offerings to his spirit and then he departs. Pablo regains consciousness and asks the rest what Ta' José has said and done in his absence!

The above account describes a typical case of Afro-Cuban ceremony, which may very often culminate in spirit possession, especially when there is music and percussion involved. This specific ritual pertained to the tradition of Palo Monte which, along with Regla (de) Ocha/Ifá or Santería and Espiritismo cruzado ('crossed Spiritism'), form the core ingredients of a complex and intricate nexus of widespread yet marginalized Afro-Cuban folk religiosity. In all these traditions, which for many people are active communicating (and communicative) vessels, spirit possession is likely to occur as part of a broader praxis in which 'the beyond' (el más allâ) is rendered immanently open to communication and interaction with the human world. Among other communicative paths, such as the employment of consecrated objects as the oracles or mediumship of less obvious external manifestation (even dreaming: see Espírito Santo 2009), spirit possession is the most visceral. The messages uttered are accompanied by explicit bodily manifestations, evinced in Pablo's voice, appearance, movement, sweat, and general body language. Even though I explicitly draw from just one person and his slave spirit, the cardinal points made to substantiate the more general arguments illuminate more broadly encountered ethnographic tendencies.

Spirits of African slaves are one of the most recurrent possessing 'characters' in Cuba and they have become the most emblematic figures of the historical imagination of slavery and, by extension, of the colonial past and postcolonial present of the island. While, for instance, the Revolution, just like the previous regimes of $\mathrm{Cuba}$, has consistently treated Afro-Cuban religiosity as an anachronistic fetishistic remnant, it has also seen a potentially revolutionary protoproletariat latency, however unconscious or limited, in the ever-present Afro-Cuban religious imagery of the slave (see Routon 2008). The broader significance of the present ethnography resides in the fact that possession by spirits of slaves is perhaps the most visceral and affective phenomenon that makes the historical imagination of slavery still vivid and not just a thing of the past to merely reflect upon, remember or forget, monumentalize or bury. Additionally, a methodological stance is adopted which does not exhaust itself on the pure imagery of slavery through spirit possession but delves extensively into what is done and said through it (see Lambek 1989; Placido 2001). If this pure imagery persists, the historical imagination of slavery through spirit possession tends to become static. Despite the (tropical) heat that permeates the pores of spirit possession, a (cold) lens comes to freeze it. In a way, we move away from a 'photographic' capture towards a 'cinematic' one, which also takes us 
out of the room wherein spirit possession occurs. Pablo and Ta' José, too, are taken out of their room.

The decision to take ethnographic subjects 'out of their room' might initially allude to a purely methodological one. But just as ethnographic subjects are taken out of their room, the ethnographer, too, is driven out of the room, whether this is the ethnographic or the conceptual one. The progressive move from a 'photographic' depiction to a more 'cinematic' one creates fertile conditions, not only for a 'thicker description' of the interplay between stagnation and motion on ethnographic terms but, equally, on analytical ones. The four following main parts of the present paper reflect precisely this constant mutual feedback between ethnography and theory, and between the imagination of the ethnographic subjects, including their spirits, and that of the anthropologist. Hence, both what this paper presents as ethnography, namely, possession by spirits of slaves in Cuba, and how broader interpretations, including academic ones, view such phenomena, are intimately intertwined.

The first main part that follows, which deals with what I call the 'formulaic' historical imagination of slavery, reflects the first crucial step, although a relatively outdated one. If one enters a similar room as that which opened the paper and leaves it to directly tell the story, so to speak, it is highly probable that description and analysis will concentrate on the most phantasmagoric and spectacular aspects. All the most direct, and largely visual, dimensions will stand out, especially when these are absent or suppressed from and contrasted to the most obvious sociality that surrounds and silences them. Here, the figure of the slave emerges, not as a dead object, but as an articulate subject, which expresses the experience of slavery as a vivid condition and as one of historical trauma.
The second main part, which I identify as 'mimesis', presents the dominant current in academic discourse which does not only express the identity of the slave as still present, but also as one which negates slavery by simultaneously making the figure of the possessing slave to emerge as an anti-slave. The third and fourth main parts, 'Limping out of Slavery' and 'Apomimesis and Negative Dialectics', precisely through a more ample ethnographic account of spirit possession, out of its room, creates a symmetrically more ample space of independence, of subjectivity, wherein the slave is partially, simultaneously, and multiply unfixed from both the monism of slavery (and its formulaic historical imagination) and the binarism of anti-slavery (and its mimesis). The main difference between the positive dialectics of the first two parts and the negative dialectics of the third and fourth is that the former heavily tread on the firm grounds of identity while the latter float on the uncharted and unpredictable waters of alterity.

\section{THE SPIRIT OF SLAVERY POSSESSES THE HISTORICAL IMAGINATION (ONCE MORE...)}

The historiography of Transatlantic slavery in Cuba, as in the rest of the New World, barring the exceptional case of Haiti, is faced up with a curious fact. While both within these postcolonial societies and outside of them, globally that is, slavery has been officially abolished and ideologically condemned, the phenomenon was not fully eradicated from the sole actions of the slaves themselves, as a final and total revolt. Rather, slave revolts have been assigned qualifications of fragmentation and complementarity in relation to the various independence movements, most often led by anticolonial and creole groups which 
wished to be radically detached from their colonial metropolises. Thus, the political subjectivity of the slaves in the larger sociohistorical consciousness has this basic view as a background and what may vary is the degree of fragmentation and complementarity of such subjectivity against this background. Academic analysis reflects all these problematics of resistance.

Apart from the effort to historicize the actual and direct slave revolts and their degree of fragmentation and complementarity to the independence movements, the relevant scholarship, and here Anthropology acquires a pivotal role, has opened an important field of inquiry concerning the more indirect and, even, symbolic acts of resistance of slave cultures and their historical imagination (Palmié 1997; see also Genovese 1976 [1972]; Raboteau 2004 [1978]; Gilroy 1999 [1993]). Anthropology seeks those indirect and symbolic imaginative instances in the ethnographic present, which is its main methodological point of reference. One such paradigmatic instance has become the religious and ritual practices stemming from slave cultures in a postcolonial context (see Stoller 1995; Comaroff and Comaroff 1999; Shaw 2002). Ritual and religion, through their performative and symbolizing capacities, are taken to be powerful weapons of the weak, precisely because they can both display and camouflage their 'hidden transcripts' (sensu Scott 1990). As such, imagination is an essentially subaltern and vernacular commentary and, within the broad field of ritual and religion, spirit possession becomes a case par excellence. This may be so because spirit possession involves intense and visceral expressiveness without relying on a wholly articulate and direct discursiveness. The body and its performative amplitude acquire central stage; the same body and amplitude that colonialism and slavery sought to subjugate and silence. One could argue that spirit possession is the perfect meeting and melting point between the body and the spirit. The haunting spirit of slavery seems repeatedly to possess the bodies of those who are-affectively, genealogically, and sociologically speaking - the most likely to perpetuate all the symbolic and physical weight that slavery has left, both as a memory and as a continuity, however transformed or disguised, in the present. Cuba, with its own colonial history, busy Transatlantic slave-holding economy, and overwhelming African diaspora, also displays the possessions/hauntings of the New World.

The first step, mentioned in the beginning of the paper, is to recuperate instances wherein the memory of slavery as historical trauma is very well alive and articulate. The opening ethnographic vignette of the spirit of a slave possessing a living Cuban body, in its most visualist representation, reflects this dimension and rightly so. Carrie Viarnés (2007: 141), for instance, terms the possession by spirits of slaves a 'subaltern discourse' that points to the 'metaphysics of slavery' (ibid.: 142), wherein is expressed a 'subjugated knowledge not to reconstruct history, but to redress it through the performance of repressed counter-memories' (ibid.: 143). Anthropological renderings of the historical imagination are very apt to precisely bring to the ethnographic fore a critical, and not always obvious, engagement with the past. This is especially important in contexts where a more official version tends to silence such 'countermemories' or freeze them as a disembodied object to be placed in a museum. Nevertheless, there is a limitation, because these memories are precisely fixed in their 'metaphysics' to be always 'counter'; and 'counter' always in the same 'metaphysical' way. The formulaic historical imagination tends to make the past and slavery (the past of slavery) the archetypical referential point (even if redressingly) of the present. While it breaks the chains of inarticulate silence of the 
figure of the slave, an important (first) step to be sure, at the same time it locks and exhausts the identity of this figure into its slavehood.

\section{THE MIMESIS OF SLAVERY}

As the anthropological theory of mimesis has been long established (see Kramer 1993; Taussig 1993), I shall be engaging with it through the Afro-Atlantic and, more particularly, the AfroCuban scholarship. The most sophisticated part of it has been indeed inspired by the mimetic perspective, and especially when it comes to the historical imagination of slavery. For instance, Kenneth Routon argues that:

Palo spirit mediums and sorcerers mimic slavery and, doing so, attempt to harness the fetish power of the slave past to contemporary projects and goals. Palo, then, provides an idiom through which the socially deleterious effects of violence and depersonalization vis-à-vis the agency of objects and objectification are expressed. (2008: 638; emphasis added)

Here we are a long way from a simple remembering of slavery and its harsh conditions, as more formulaic renderings of the historical imagination do. The past and the present become more equal interlocutors through mimesis. But it is not only 'violence and depersonalization' which are expressed through the ritual mimesis of slavery in spirit possession. This 'harnessing' of the past to 'contemporary projects and goals' seems to be accompanied by a more dynamic interplay between empowerment and disempowerment: 'certain historical events are sometimes reified as magically empowered imagery capable of both causing misfortune and expanding people's power to act on the world' (Routon 2008: 633). Or, as Elizabeth Pérez corroborates (2011: 353-354): 'a replaying of the past with a flipped script (...) a stirring critique of the past from the perspective of the present'. And as she also argues, showing that mimesis also puts into close dialogue resistance and accommodation, in such a way we: 'relinquish any investment in situating religious subjects solely according to their complicity in or opposition to their own domination' (ibid.: 354 ). The kind of empowerment that mimesis affords is, at least, double. It might be an empowerment in a resisting sense or in an accommodating sense:

to construe the matter in terms of polar opposites masks the fact that much of what we should consider the slaves' most remarkable achievement (...) was based not on resistance pure and simple, but on some measure of accommodation as well. (Palmié 1997: xvii-xviii)

In both cases (in resistance and in accommodation) an act of transformation occurs through mimesis. The 'weak', by the very own means and terms of the 'strong', empower themselves and become strong(er). Here I take slavery (as well as colonialism in total) as originally a 'means' and 'term' of the strong, which only subsequently come to be transformed into one's own means and terms of empowerment, as well as disempowerment of the 'enemy', whoever this is deemed to be, postcolonially speaking. The oppositional binarity that is entailed is not static but dynamic, exactly because within it lurks the possibility of reversibility (see Keisalo 2016; Pillen 2017). It is precisely this possibility, whether virtual or actualized, that transforms a curse into a blessing; this is the 'magic of mimesis', if you like, and to echo Michael Taussig (1993: 16), 'wherein the replication, the copy, acquires the power of the represented'. 
The slave becomes an anti-slave in a ritual homeopathy of slavery's own phantasmagoric image. 'Thus, in these religions, redemption from affliction and misfortune often entails a new form of privileged enslavement' (Matory 2007: 416).

Close to the ethnographic context I am drawing from, the mimetic possibilities of reversibility have been artfully extended to their more general Afro-Atlantic (see Johnson 2011), 'archeological' (see Apter 1992), sociohistorical (see Palmié 2002: 159-200), performative (see Hagedorn 2001; Wirtz 2014), gendered, sexualized, racialized, and diasporic (see Beliso-De Jesús 2015) dimensions. The mimetic framework creates a tension beyond the one encountered in the formulaic historical imagination. If the tension created in the latter is that between inarticulate and articulate historical trauma, mimesis goes a step further. The tension here is between an articulation of historical trauma and the articulation of something that reverses the trauma into a kind of privileged affirmation. The silence that reigned over the historical imagination of slavery augmented the disempowering position that slavery imposed. In fact, these are sides of the same coin, as domination establishes itself as such simultaneously through unilateral imposition and through silencing any voice that would question it. The expressiveness of spirit possession, even if unable to overturn the institution of slavery as such, at least has embodied the trauma and brought it to the surface. The mimetic framework goes a step further in the sense that it gives room for the expression not only of the traumatic dimension of slavery but also of the tension that exists in its possibilities of negation.

This tension is a dominant paradigm in the broader ethnographic context that surrounds possession by spirits of slaves in Cuba, but also spirit possession in general, in Cuba and elsewhere, as the expression of subalternity. Generally, this can be evinced in the literature from the passage of studies such as that of Ioan M. Lewis (2003 [1971]), through ones such as Janice Boddy's and leading to mimesis itself (see Boddy 1994). More particularly in Cuba, the dominant mimetic framework entails both a liberating dialectical step beyond the more formulaic paradigm of the historical imagination of slavery and a certain impasse, which is surpassed by the proposed ethnographic concept of apomimesis developed in the following sections.

Possessing spirits of slaves condense and exemplify a broader Afro-Cuban religious idiom and instantiation of the ambiguity that characterizes almost any entity inhabiting this polytheistic cosmos, whether it be a spirit of a dead person or a deity. The ambiguity lurks in the fact that aspects of each entity (and of the relationality honed through them) might be either beneficent or afflictive. Nevertheless, there is an added dimension in this ambiguity concerning spirits of slaves (or others, which are considered as having lived a life and having suffered a death particularly violent and/or in affliction). Very often, such spirits may act much more arbitrarily and unpredictably than other more 'enlightened' spirits or more seemingly stable deities. Therefore, the relations cultivated with them are fraught with even more ambiguity and a hierarchy in constant tension.

Stephan Palmié (2002:176) has argued that there lurks 'a historical cogent twist [in the] possibility of revolt'. Speaking of the nganga ritual material complex of the Palo Monte Afro-Cuban tradition, which may host the spirit of a slave or another afflicted and afflicting entity, he argues: 'If treated improperly, ngangas may be rendered ineffective. But they may also turn against their owners, consuming their 
persons in a phantasmagoric transformation of the Hegelian image of the dialectics of dependence between master and slave'(ibid.). In this ambiguity can be added another dimension, common, even if stereotypically, of the potentiality of spirits of slaves, namely, that one person may benefit through harming another. A common term describing all these tensions of reversibility is that of brujeria ('witchoraft').

Here we have three interrelated dimensions of a Hegelian-inspired positive dialectics which nurture the mimetic framework. Firstly, the ritual manipulator (the palero or the person whom he attends) of the nganga becomes a master of the material and spiritual forces residing in it, and more specifically the spirit of a dead person, whether a slave or not. Secondly, these forces may rebel and turn against their human master. Thirdly, both parts may become masters in tandem against the affliction or enslavement of a third part. If this third part mobilizes and contracts his or her own similar material-spiritual forces in turn, then a multiplication of these dialectics infuses all the sociality (and anti-sociality) which is simultaneously instantiated. The mimesis of slavery empowers the slave, whether this is a living human being or a spirit, and whether virtually or actually, to negate slavery, to become an anti-slave by the simultaneous possibility of enslaving another person-entity. Slavery and anti-slavery are dialectically related. The question arises whether the negation of slavery is exhausted in the figure of the anti-slave who desires to become a master by enslaving its previous master.

\section{LIMPING OUT OF SLAVERY}

'What can you do about slavery? Nothing: this is long gone. What you can do something about is the slaves themselves and the people who cross paths with them'. This exclamation was uttered by a Cuban friend of mine, initiate and practitioner of Afro-Cuban religiosity. It has proved to be a moment of ethnographic inspiration, reflected in the very title of this paper. A similar exclamation referring to the slavery period in the United States was made, although on a more ironic tone, by Nijala, an Afro-American spiritualist interlocutor of Elizabeth Pérez: 'Those days are over (...) We's free now' (2011: 353; emphasis in the original).

Ta' José appeared at a time when Pablo was experiencing a deep 'sinking' (bundimiento), as he calls it. After a prolonged period of academic formation, taking place in the effervescent and promising decade of the 1960s, wherein the Revolution was urging, even pushing, for a 'mobilized' and 'participating' citizenry, what progressively and disappointingly followed was this 'sinking'. His adolescent and early adult dreams were to become an intellectual of sorts, while also actively participating in the formation of the new society the Revolution had set out to forge. According to Pablo, the 'sinking' occurred on two levels: firstly, he felt that the promises of the new society had been displaced by an authoritative state of vigilance, which in his case also curtailed intellectual expression; secondly, his scholarly aspirations were not remotely matched by a decent source of stable income. As he said: 'Instead of the Revolution abolishing class differences, making us all middle-class, neither rich nor poor, it abolished them by making us all working-class'. It is in this progressively 'sinking' period that Ta' José emerged limping, in pace with Pablo's life-course. Note, in advance, the interesting ethnographic articulation of experiences of movement (and their obstructions), in their equally literal and metaphorical (or else, physical, verbal, mental, emotional, psychological, and existential) manifestations. 
Pablo says that he did not grow up in an environment steeped in Afro-Cuban religiosity. The two main sources of acquiring familiarity with it were, firstly, his neighborhood and, secondly, his membership of, and regular visits to, the Union of Writers and Artists of Cuba (Unión de Escritores y Artistas de Cuba), where he met intellectuals who had both 'academic and personal' involvement in Afro-Cuban religiosity. An initially 'purely academic interest' transformed into a kind of 'fascination and inevitable degree of personal involvement'. Through a long and intricate reception of utterances, from different sources, entities, and Afro-Cuban religious traditions, Pablo started 'finding [his] path' within this complex cosmos, initially solely as a receiver of utterances and progressively also as a transmitter.

Ta' José first made his appearance abruptly and violently. In a similar ceremony to the one described and, again, amid wild drumming and heated movement, Pablo momentarily lost his usual self and his path crossed with that of Ta' José. People described the possession as one that 'didn't make much sense', full of jerky movements and almost unintelligible utterances, gibberish, except for the fact that they 'sounded like African gibberish'. Pablo, while possessed, tore his t-shirt, and limped conspicuously, accompanied by the repetitive movement of raising and lowering his arms with his fists clenched and adjacent. While both the formulaic historical imagination and the mimetic perspective, in their visualist bias, would tend to end ethnographic description of spirit possession somewhere here, I proceed with what initial visual clues are generative of. Based on these few clues, Pablo was urged by the ritual elders who were present to construct a 'representation' (representación) of what were presumably the first 'manifestations of the spirit' (manifestaciones del espiritu). These were translated into the material construction of a doll which was black (due to the 'African gibberish'), with no clothes on the upper body and holding a pick (due to the movement of Ta' José's arms, unanimously interpreted as indicating labor with a tool). The doll was placed at the house of Pablo's ritual 'godfather' (padrino), where it received certain invocations and offerings, including sacrificial blood.

The common understanding was that $\mathrm{Ta}$ José's excessively visceral manifestation was the result of an inability to communicate, and a parallel, urgent need to dispel the obstacles causing this. Consequently, one could say that this inability was not total because in its inarticulacy (see Vitebsky 2008) the urge to overcome it was itself the 'message'. As Ta' José had chosen Pablo out of a sense of 'affinity' (afinidad), the way forward was to put the two into intimate and multiple dialogues. If this had not happened, Pablo argues, both would have remained in a state of stagnation or deviation, of inarticulacy. Pablo would have continued to experience his personal 'sinking' and Ta' José his 'aimless wandering' (ir vagando); now, however, due to Ta' José's being 'attached' (apegado) to Pablo, the two initially distinct inarticulacies would in future be mutually nurturing, leading to further inarticulacy and biographical 'deadends', or at least 'sinkings'. Neglected entities, thus, are usually both the source of affliction and their subsequent being paid attention to, often by way of initiation or other ritual care, is the remedy against affliction.

During the period between the first possession by Ta' José and the assembling of the doll, Pablo experienced an intensification of his 'sinking'. Apart from general and prolonged feelings of meaninglessness, existential inertia, and depression, Pablo developed an intense pain extending from his right leg to his back which practically paralyzed him. 'This was the sinking 
of my sinking', as Pablo graphically puts it, 'carrying not only my weight [ carga] but that of Ta' José too'. Pablo's understanding, completely compatible with and, thus, representative of a broader Afro-Cuban religious view, is that the very first case of spirit possession brought to the surface an initially limited and limiting situation. As noted, the general hypothesis raised by witnesses of the event was that Ta'José was the spirit of an African slave. Nonetheless, the doll was not constructed solely based on this hypothesis, but also on account of the visual clues presented by the possession as described (perhaps the most hypothetical element being the pick placed next to the doll). As soon as the doll was 'prepared' (preparada) and various invocations and offerings were made, Pablo's paralysis progressively vanished. In subsequent possessions, the people present started to decipher utterances which provided confirmation that Ta' José was the spirit of an African-born slave who had died violently and prematurely from a fatal infection in his right leg, caused by being constantly chained during arduous rural labor (for an interestingly similar ethnographic description, see Pérez 2011:351352).

Considering that spirit possession, like other forms of mediumship, is generally taken as an alleviating sign of spirit-human interaction, I ask Pablo how he interprets his paralysis. He says, again largely in accordance with general understandings, that Ta' José was not even conscious of being dead: 'This is why, in his possessions, without saying much and with no apparent sense, he would mechanically and repeatedly move as though hoeing the soil, as he did as a slave when he was alive'. This is interpreted by Pablo as the source of the paralysis because Ta' José's biographical tragedy resurfaced unreflexively through Pablo's body. As he understands it, Ta' José identifies excessively with two things: firstly, his own past as a suffering and living (not dead) human being and, secondly, with Pablo's (living) person and body. His 'affinity' with Pablo is explained on the basis that both persons, Pablo and Ta' José, found themselves in a state of stagnation or deviation of their paths from their course: 'Our paths crossed in their derailment'. The first case of spirit possession is seen as a nodal point in this crossing of paths, primarily because it exhibits, in the most obvious of forms, the biographical tragedy of Ta' José's life as a slave and his untimely death, an obstructed trajectory which is linked to Pablo's own biographical 'sinking'; and, secondly, because it does not represent a static point, which would subsequently serve merely as a 'symbol' for repetitive reflection (formulaic historical imagination). Rather, this spirit-human intersection provides a point of departure, deviating significantly from its purely reflexive and symbolic aspects, because a dynamic and often experimental process of converting a state of inarticulate stagnation into articulate motion takes central stage. The act of this conversion is capacitated by a stance of 'negativity', not of the construction of a certain identity, the reified slave (formulaic historical imagination) or the anti-slave (mimesis) but the non-slave (through processes of apomimesis, as it will elaborated).

Pablo mentions that the first actions taken were focused on 'letting the spirit see' (bacer que el espiritu vea) that he was dead. Pablo argues that the reason for this lies in spirit possession per se, during which process the spirit starts to see itself out of its own body and inside that of somebody else. But this is not enough because a body, after all, is 'very much alive, even if it's not yours', Pablo adds. Here the doll plays a crucial role because, through its partial resemblance to the spirit's biographical past (the hints he provided himself), it serves as a further step in 
departure. It is this partiality that is interesting, because it simultaneously walks the line between both remembering and identifying with the past and deviating from it: 'Dolls are "materializations" [materializaciones] of spirits whose previous physical body has perished, and this is exactly what they remind the spirits of', comments Pablo. As much as the clues serve to draw the spirit close to the doll, this treatment must be administered as a measured dose, so as to partially make them remember and partially make them forget (their embodied and living condition; for more details, see Panagiotopoulos 2017). One could say that these dolls are the means to render life a representation and death an actuality, simultaneously; the past life finally dies (hence, it can only be represented), while the present death is instantiated as a transformation: as only able to possess other kinds of bodies, such as Pablo's or the doll's, in its disembodied, or rather, disembodying condition. Dialectics involve both processes of embodiment and disembodiment; 'negative dialectics' do so in their constant, unresolved intertwinement.

After the spirit of Ta' José becomes more conscious of its own death through seeing its past life represented in the doll or the body of Pablo, a gradual transformation occurs. To begin with, his 'African gibberish' starts to become more articulate. Still preserving a certain 'African' accent, he is now much more intelligible to the people witnessing his possessions. As we saw, soon after the doll was 'prepared', Ta' José verbally provided some biographical information, limited to his past as a slave, which led to an infected leg and limp and eventually a tragic death. Though intense, the information was not to be repeated nor enriched with further biographical detail. Subsequent possessions progressively turned the light onto issues of the ritual life of the specific 'religious family' (familia religiosa) and, in general, the people witnessing the possession events. As for effects on Pablo's life-course, he attributes his emergence from his previous 'sinking' to his crossing paths with Ta' José. This is not only because his consultations and the support afforded others through his being possessed became a vital and vibrant part of his life (even including personal material gains) but also because his scholarship encountered a new and inspiring subject of study, namely, AfroCuban religiosity.

Now Ta' José possesses Pablo without replicating the mechanical movement of wielding a farm implement. He makes Pablo limp and sweat as he himself did in the vast sugarcane fields of colonial Cuba, but these affective articulations are not so intense as in the beginning and, more importantly, they are not the sole activities. Parallel to them and, I would argue, despite them, Ta' José, along with Pablo, is now able to enter a broader field of articulate motion in which the past of Ta' José as a slave is neither annihilated nor yet all-encompassing. It becomes a past to be remembered and represented in an important but actively limited way. In its very instantiation, amidst the limping and the sweating, it is also obviated so that stalled or deviating paths may acquire more desirable and open directions. As in colonial times, slavery is still a point of violent possession and departure, never a welcoming harbor. Aggressive resistance to, or passive acceptance of, such a condition would hardly exhaust all the possible and viable paths, while a 'hidden transcript' (à la Scott 1990) that would merely mediate and, in the final analysis, sustain the monopoly of the two poles is also not wholly satisfactory. 'Negativity', neither angry nor mute, would most adequately describe that path of possession: a negativity that declares a partial but vital independence and non-referentiality to slavery itself. This 
transforms the causal 'because' into an active and uniquely articulated resisting 'despite': despite slavery and despite all the racism that it is its residue even long after its abolition, Ta'José's biography, in its crossing with that of Pablo and those others that surround them, is unchained from slavery and anti-slavery. Through this dynamic and experimental articulation of utterances and mobilization, Ta' José decisively limps out of slavery! Although the limp persists, somewhat slightly alleviated, it breaks the chains of inarticulacy. Oracular articulacy flows and the 'paths' of both Pablo and Ta' José, in their crossings, get out of their 'sunken' state. As Pablo exclaims: 'One could only presume that this was exactly what he did when, while alive and enslaved [and despite the latter, I would add], he was himself being possessed by his own deities and spirits of the dead'.

\section{APOMIMESIS AND NEGATIVE DIALECTICS}

If seen in an 'evolutionary' scheme, the present ethnography might suggest a linear and progressive dissociation from slavery, as the first violent and inarticulate possessions are replaced by smoother and more articulate ones. And as they do so, slavery itself is displaced from its central (visual) stage. It would, thus, seem that we are dealing with a sequential reversibility of sorts. But this would be too hasty and inaccurate a description. Reversibility is neither sequential nor digital but simultaneous. Spirit possession, and especially the first cases of them, brought Pablo and Ta' José extremely close. Pablo does not empathize with slavery but with $a$ slave and such empathy is neither an absolute end, nor is it perceived as something automatically positive (c.f. Bubandt and Willerslev 2015). Too much identification would maintain the two paths crossed in their 'derailment', an unreflexive and passive meeting of deviated and stagnated paths. But this does not lead to an absolute reversal, to an excessive differentiation.

The initial cases of its manifestation intensely stress an empathetic state of the spirit's impaired (body-) language. Restricted and mechanical movements (limping and wielding a farm implement), African gibberish', and so on. Spirit possession proves a nodal point, and its first instances accentuate inability and misfortune in provoking paralysis in Pablo. It is only after efforts to open dialogue and exchange with the perceived spirit that things start moving, and two apparently distinct biographical paths, those of Ta' José and Pablo, in their derailment cross each other, to echo Pablo. If it is empathy that is stressed through possession, this is not a stable and static state. As Ta' José limps around, he starts offering oracular utterances to those present, listing their small or large 'sinking' and biographical dead-ends. The more Ta' José is able to articulate himself, initially through the intense empathy and affectivity of possession, the more the experience of slavery is able to find its way out of the static and impaired state it is meant to be instantiating. It is not that slavery becomes a mimetically empowering state of motion and wellbeing, but that its very un-doing breaks the slave-chains of inarticulacy through the empathetic crossing of $a$ slave with $a$ living human-being and the rest of the people who cross paths with both. It is not the past of slavery that resurfaces but the biography of a slave and the empathy between it and the biographies of its living interlocutors.

If it is empathy that initially acquires central stage, a parallel soon develops, one that is antithetical but complementary in the larger scheme of relationality. Through its empathetic instantiation, a process of differentiation is ignited. Slavery is progressively decontextualized through spirit possession by becoming a symbol 
of itself and, at the same time, an instantiation of its partial undoing. The initial possessions by Ta' José are translated into a material 'representation' via the indigenous idiom of a doll bearing visual signs of the slave's biography, but both the understanding and the experience of this step are significant transformations and differentiations from slavery. The material 'representations' facilitate the spirit's becoming aware of its own death. The partial resemblance of the doll is accompanied by a partial differentiation because, in Pablo's indigenous 'theological' explanation, Ta' José starts seeing himself out of his past embodied condition. The experiential transformation results in a less stagnant and inarticulate state for all. Subsequent possessions are less visceral, certain movements disappear (the wielding of the farm implement), while others (the limping) level out, giving way to a less obstructed flow. The 'African gibberish' not only becomes more intelligible, but its content begins to have more to do with the spirit's present desires (mainly offerings and sacrifice) and oracular diagnosis and remedies for Pablo, his 'religious family', and the audience. Slavery is abstracted to become an example of a much more generalized and multiple experience of misfortune, of stagnant and deviating paths, which in their derailments cross each other and, in their crossings, find a way out. The same occurs with all Afro-Cuban entities and not just spirits of slaves, as their afflicting potentiality is sought to be minimized and reversed into a benevolent one.

While the specificity and individuality of the biographical empathy serve to produce the necessary material constellations that embody, activate, and concentrate the perceived spirit, the simultaneous abstractive tendencies make an equally significant contrast. They obviate from those biographical elements that provoked an impaired path to the spirit's own biography, as the latter is slowly translated into the biographies of the living humans who cross paths with it. To cross paths, a certain degree of differentiation is required so that both biographical ends fit into a mutual exchange and dialogue of identifications and their subsequent transformations and obviations. In the larger scheme of Afro-Cuban oracular relationality and articulation, both identification and differentiation are necessary, contrasting, and complementary ingredients. Identification and differentiation feed off and cancel each other simultaneously, with parts preserving their autonomy and other parts transforming through being affected by their counter-parts.

As Diana Espírito Santo (2015) argues, explicitly for spirits of the dead in general and not just of slaves: '[T]he Self here is acquired outside itself, as much as it is seen as a potentiality inside it; this also means that the "not me" or "not Self" portion of Self is highly consequent in revealing the "me" or "Self", particularly if it occasions illness or misfortune' (Espírito Santo 2015: 268). These crossroads of Self and Other (also appearing between interiority and exteriority in a process of 'infoldings' and 'outfoldings', as Espírito Santo terms them) are linked to notions and experiences of harnessing or blocking motion. They are, as Beliso-De Jesús aptly puts it, 'crucial nodes of adhesion and disarticulation (...) an important geographic spiritual locator, spatializing one's relationality with good and bad things that may come one's way, [nodes that are linked to] social-spiritual notions of travel' (2013: 712) that add 'perceptual religious dimensions to mobility' or, as Martin Holbraad frames it, 'motility' and 'directed motion' (see Holbraad 2007; see also Lems and Tošić 2019). What I have described, therefore, is not only 
limited to possessions by spirits of slaves, but refers, in one way or another, to a variety of entities met in the broader Afro-Cuban cosmos.

There are similar concepts which could be linked to mimesis. For instance, that of 'counterpoint', which has a special affinity to the Cuban intellectual milieu (see Ortiz 2002 [1940]). As it has been noted and beyond its strictly musical domain, counterpoint, as a relational modality, involves contrasting 'voices'. But the contrasts, instead of being exclusive of each other, they are inclusive (see Panagiotopoulos and Espírito Santo 2019). The outcome is a heterogeneous whole which remains as such by way of tension, mutuality (symmetry), and hierarchy (see Holbraad 2019; Seremetakis 1991: 112-116). Another similar concept is that of 'antiphony', which has been also linked to divination, as well as ritual lament, in rural Greece (see Seremetakis 1991: esp. 99-125). At some point in Seremetakis' analysis, we are given a clue of how antiphony or counterpoint may emerge. Her answer, referring to the ritual lament (kláma) of the Maniat women, is that of 'polyphony':

Polyphony is the raw material for the antiphonic practice. By polyphony I mean the improvised, heterogeneous, and superimposed linguistic, extralinguistic, musical, nonmusical, poetic, and prosaic discourses that constitute the performative aesthetics of the klama. The antiphonic relation emerges as an articulation between these linguistic and extralinguistic media, between poetry and prose, music and screaming, and it is distributed and redistributed through this multidimensional polyphony. (Seremetakis 1991: 106)

Polyphony, as the 'raw material' of antiphony, is the potentializer of the latter due to its own possibilities and limitations: 'The polyphony of the ritual does have limits that indicate a hierarchy in the order of discourse that must emerge in order to generate the formal antiphonic relation' (Seremetakis 1991:112). The Maniat women's divinatory lament (the equivalent of the Afro-Cuban slave possessions) indexes both their historiographical subalternity in a male-, Christian-, modernity-dominated Greek society, and the reversal of such position in the act of forming a powerful contrasting 'chorus'. Seremetakis' point begs the question of how it is possible for antiphonic mimesis to entertain reversibility and simultaneity. I believe that an important part of the answer lies in the notion of 'negativity', as inspired by the suggestive but obscure writings of Theodor Adorno and the concept of 'negative dialectics' (see Buck-Morss 1979; Fabian 2001: 87-100; Adorno 2007 [1966]; 2008 [2003]). It is within this kind of negativity that mimesis is complemented by its apomimesis.

If mimesis remains orphan, without its negation, then, sooner or later, it is swallowed up by the reificatory appetite of identity. Apomimesis, then, stands as its counterpoint in a negatively dialectic fashion, which does not resolve the antithesis by synthesis (Hegelian 'idealistic' dialectics) and thus merely performing an expansion or adaptation of identity, but puts it in an unresolved tension with alterity:

Idealistic dialectics also was an 'origins' philosophy'. Hegel compared it to a circle. By its return to the starting point of the motion, the result is fatally annulled; this was supposed to bring about a continuous identity of subject and object (...) Throughout, the Hegelian synthesis is an insight into the insufficiency of that movement, into the cost of its reproduction, so to speak. (Adorno 2007: 156) 
Taussig, although he continuously alludes to the dialectical relation of mimesis and alterity, proving more dialectical than Hegel, sticks more to Walter Benjamin's attractive mimetic style than taking on Adorno's propositions into their fullest implications (and complications). This is illustrated by Taussig's fascination with the somewhat obscure remaining similar, not similar to something, but just similar (Taussig 1993: 240, quoting Caillois 1984). The obvious negatively dialectic counterpoint of this would be remaining other, not other to something, but just other. But this should not replace the mimetic excess but create an open (not circular) tension with it, a counter excess:

dialectics means to break the compulsion to achieve identity, and to break it by means of the energy stored up in that compulsion and congealed in its objectifications (...) As the concept is experienced as nonidentical, as inwardly in motion, it is no longer purely itself; in Hegel's terminology, it leads to its otherness without absorbing that otherness. (Adorno 2007: 157)

In final analysis, the problem with mimesis is its excessive adherence to an abstract and purist notion of 'power', a category that I argue falls prey to the devouring appetites of identity. The reversibility qualities of mimesis capacitate the objectified subject to become 'pure' subject by seizing (a verb, along with the term 'power', often employed by Taussig) the power-position of the subject which had previously objectified it. Now, the object-cum-subject turns the tables and becomes the powerful objectifier (the copy) of the (original) objectifying subject, it mimics and instantiates its power to objectify. The table or the chairs are turned but the furniture remains on its feet. The slave becomes antislave, that is, a slaveholder or a master of sorts, whether representationally (as mimesis points to) or historically (see the case of Haiti, for example). Apomimesis, on the other hand, leaves vital room for the slave to also become a non-slave, to negate slavery, slaves and slaveholders, altogether, even though partially or momentarily.

it is not the purpose of critical thought to place the object on the orphaned royal throne once occupied by the subject. On that throne the object would be nothing but an idol. The purpose of critical thought is to abolish the hierarchy. (Adorno 2007: 181)

Apomimesis adopts the orphan mimesis by abolishing the power structure that had seized or, even, killed its kith and kin. Adorno's 'critical thought' points here to the negative dialectics which bring at a crossroads the imagination of ethnographic subjects and facts with the imagination of the anthropologist, not to uncritically replicate or ignore a stable reality (Adorno's 'throne') but transform it by creating points of departure and not teleological points of permanent and secure rest. The ethnographic instantiation of all this is the constant effort of Afro-Cuban religiosity to generate oracular articulacy (a flow of words and biographical 'paths') at the crossroads of partial identifications and differentiations between humans and nonhumans (see Panagiotopoulos 2018; see also Willerslev 2004).

To return to Seremetakis (1991), antiphony is generated through polyphony. The latter encompasses the former, but due to its limitations, it is also superseded by it. One could say that the infinity and hyper-relativity promised by polyphony can never be actualized, so antiphony takes over as it is more realistic and less utopian, more formal, as Seremetakis puts 
it, than polyphony. Indeed, absolute infinity and relativity seem to be ultimately (not to say in principle) unattainable. Nevertheless, and here lies a common tendency of misunderstanding negativity, the negation of something is hardly exhausted in being or becoming its opposite. This is for two intimately interrelated reasons. Firstly, the opposite of something is not a fixed, universal, ahistorical, and idealistic principle. Secondly, the negation of something is not necessarily its opposite, exactly because of the previous point, but even if indeed opposites were absolutes, at least in a contingent spatiotemporal context, or when they appear to be so through hard hegemonic (ideological and coercive) work. Not to be something or to become something one is not, does not by necessity mean to be(come) its opposite. This is only one path, a common one, among others. Maniat women do not become Maniat men; Afro-Cuban slaves do not become slaveholders. Alterity must also breathe in a more negatively open space; not just within its conventionally dominant 'opposite'.

All these points are particularly apt when it comes to slavery. What is the negation of slavery? Even if we pose the question in its more historically naive form, that is, in terms of absolute opposites, the answer is hardly straightforward. One could jump up and fervently shout: 'Freedom! This is the opposite of slavery! Freedom is indeed the opposite of slavery, just as well as slavery is the negation of freedom. But freedom is hardly one thing, and it can also be negated by means other than slavery (unless we axiomatically define or metaphorically call 'slavery' whatever negates freedom, whatever freedom might mean: a circular dead-end; c.f. Adorno 2007: 211-299). Freedom, hence, is polyphonic, and only one version of it is antiphonic.
To be possessed by the spirit of a slave brings slavery, so to speak, down to earth in an extremely personalized and visceral way. Even if this sounds counterintuitive, this already constitutes a first step towards a peculiar kind of negation of slavery. Spirit possession is not an abstract reflection on slavery as a totality, but a confrontation with $a$ slave with a name, with his limp, his sweat, and his 'African gibberish'. As we saw, a simultaneous process of differentiation occurs whereby the spirit is reminded of his past as a past, and not as a present. From an excessive and unreflexive flooding of the past into the present, things start being relativized by partially identifying with the past and partially differentiating from it. This kind of simultaneity vitally requires partiality because the former is not only a virtual (promise or threat) but constantly actualized and experimentally readjusted. Just as extreme identification, empathy, and contingency with the biography of the slave is a perilous condition, the extreme opposite is neither a desired outcome. Material constellations (such as consecrated dolls), ritual offerings, even spirit possession itself, should entertain simultaneously identification and differentiation, memory, and oblivion, so that the articulation of oracular utterances and all the 'remedies' they prescribe flow with clarity and abundance.

To go against the past of the slave in oppositional terms would require either a total and forced oblivion of it or an open and permanent reference to it. Both extremes are perceived by adepts of Afro-Cuban religiosity as obstacles. Even in terms of resistance and accommodation the total referentiality to slavery is not lost with the mimetic stance, as to either resist or accommodate slavery, just as to do both at the same time, would be direct responses to slavery. To negate slavery, what is partially 
needed is to refuse to make it an absolute referential point, to refuse to respond to it (for interesting discussions on the sibling concept to negation, that of 'refusal', see Yurchak 2008; McGranahan 2016). I think that this is precisely what Pablo's opening words to the Limping out of slavery section reflect, that you can do nothing about slavery: 'this is long gone'. As with other spirits of the dead, be they gypsies, Arabs, native Indians, monks, intellectuals, pimps, prostitutes, doctors, relatives, or strangers, those of African slaves have a potentiality which needs to be unleashed. The identities and biographies of all these spirits are initially in a state of inarticulate derailment as this is 'crossed' with the inarticulate and derailed paths of their living human counterparts. Just as their past identities must be partially reconstructed in the present, at the same time, they cannot be replicated, precisely because that would lead to stagnation. This is for two interrelated reasons. Firstly, the identity of a subject or a person, be that living, dead, or divine, is not a finished state. Secondly, because its 'archetypal' manifestation should not be exhausted in what makes it an archetype in the first place. A slave, as any other spirit, was never just a slave and, thus, becoming just an anti-slave would never be able to exhaust what a slave is not. The condition of slave for spirits of slaves is the definite reason for such derailments and the main obstacle to be overcome.

As much as this condition is part of the biography of the spirit, it cannot be obliterated, as it cannot be accentuated either. But this radical simultaneity of opposites is not the only issue here. Other biographical elements come to the fore, by way of an archeological excavation of sorts. There is a common biographical element that is excavated, not as a dry piece of information to be placed into a museum, but as something to 'develop' (desarollar) into what could be called not just a remembered biography of the past but an active articulation of a vivid and not preordained present (or else, 'necrography'; see Panagiotopoulos 2017). This element is a general 'witchcraft' (brujeria) knowledge and oracular sensibility that spirits of African slaves are perceived to carry in potential and par excellence. It is precisely the actualization of such potential that is unleashed and runs parallel to slavery as the 'limping' biographical past of the spirit.

Slavery is the contingent fact that Africans were brought to Cuba in such condition, but it is not the determining factor of their magic. The most powerful, deep magical knowledge is considered to come from an imagined 'African' pre-slavery past and it is this knowledge which is also sought through contact with spirits of Africans. What happens to slavery is a kind of active negation, so that the magic is unleashed with no impediments, no limps, and chains, or despite them, to be precise. As this negation is not total but partial it leaves room for mimesis too, just as mimesis leaves room for the more formulaic historical imaginations to unfold, because it encompasses them. This kind of apomimesis encompasses the 'either/ or' and the 'both/and' structures by adding into them a 'neither/nor' structure, which is itself de-structuring, partially but radically so, because it unleashes with no relativism intended all the magical and oracular articulations that are squeezed into it. Partiality and negation are vitally complemented with multiplicity, the third building block of the non-fundamentalist pillars of apomimesis.

\section{NOT SLAVERY... WHAT ABOUT ROYALTY?}

Along with the recurrent appearance of spirits of African slaves, a striking counterpoint coexists. This is the royal quality that is invested in many 
a deity, especially those pertaining to the Ocha/ Ifá (Santería) tradition (see Brown 2003). While Palo Monte stands on one side, crammed with spirits of African slaves, Ocha/Ifá stands on the other, wherein the orichas are mythologically depicted as royal figures which, by way of initiation (neophytes are 'crowned' [coronados]), confer their royal qualities to humans (see Palmié 2002: 159-200). Even though each tradition seemingly stresses such opposing qualities - royalty and slavery respectively - in a clear-cut fashion, things, I argue, are far more complicated.

Both the identities of the entities and the relationality hatched through them condense a tension that could be said to oscillate between a hierarchical scale of dominant-actant and subordinate-acted-upon. This is not a rigid structural state between royal deities and serving adepts or spirits of slaves and their human masters. The condition is not static because it can potentially be reversed, both within a given entity and its human counterpart and within the whole relationality which involves multiple entities and multiple living humans and their perpetual interactions, including conflicts of interests. In this larger scheme, the historical imagination and mimesis ultimately collapse and bleed into each other, like drops infusing the sanguine Transatlantic vessel. The potentialities unleashed create a dizzying spiral of kings and masters becoming slaves and vice versa, a looping Hegelian dialectics of masterslave perpetual synthesis and ana-synthesis.

But as I hope the present paper has managed to flesh out, a parallel 'gear' is also at work, where the whole spiral is negated through the partial differentiation from the mythobiographies of deities and spirits of the dead. The effort, not at all guaranteed, is for oracular articulacy to flow beyond the structural synthesis and reversibility between 'royal' masters and enslaved serfs. The non-slave surfaces out of the dialectical tension between the slave and the anti-slave (the master) and both terms are partially negated and rendered powerless.

I will try to convey all these previous points with a, hopefully, imaginative metaphor. Wheeled and motored vehicles, to move and carry ('metapherein', in Greek) have, most commonly up to now, needed a gearbox. All changes in gears are capacitated by the neutral position. Movement commences, passes through and is terminated by it. The neutral is, hence, a vital generative position between any two others. In Seremetakis' (1991) terms, it would be the polyphonic 'raw material' of vehicular, literally metaphoric, motion. Let us say that the more formulaic historical imagination of slavery is the first gear, while mimetic reversibility is, by its op-positionality, the reverse gear (although in terms of temporality, the inverse would be more apt, as the mimetic stance looks more forward and the 'historical' more backwards). The apomimetic stance, proposed in this paper, would stand as the neutral position that mediates between the first and the reverse gears. But much more than a mediator between the two op-positions, the neutral is the facilitator of other possibilities, other gears and positions. The neutral, thus, may negate the negation that reversibility performs and may open the road towards other directions, paths, and crossroads. Slavery, the slave and the anti-slave, are partially negated, so that their magical and oracular articulacy is 'positively' unleashed, which, in their turn, unleash the flow of the biographical 'paths' of their human interlocutors.

All this also offers an alternative and parallel historical imagination. Remember what Pablo imagined through and of Ta' José, described in the third section: 'One could only presume that this was exactly what he did when, while alive and enslaved, he was 
himself being possessed by his own deities and spirits of the dead'. Then the roles were possibly reversed, with the slave himself being possessed by a (free?) spirit. Whatever the partial identities and partial alterities of that past, through the ethnography we can imagine that even back then oracular utterances, magical spells, sacrifice, initiations, were instantiating 'sorcery out of history' (Routon 2008: 638), not only as a kind of mimetic appropriation and empowerment, but also 'out of' it in the sense of departure: of a double-bind of having to live with but not wholly be conditioned by slavery and its conventional history. Multiple and parallel histories and imaginations were and are at stake. Slaves were never just slaves. They were and are slaves, anti-slaves, and non-slaves, simultaneously.

\section{ACKNOWLEDGEMENTS:}

I am grateful to my host institutions, Centro em Rede de Investigação em Antropologia (CRIA; project ref. no.: UID/ANT/04038/2019) and Faculdade de Ciências Sociais e Humanas (FCSH), Universidade Nova de Lisboa, Portugal, as well as the Portuguese funding body of Fundação para a Ciência e a Tecnologia (FCT; project ref. no.: DL 57/2016/CP1349/CT0008). My debt is also extended to the research project I am currently participating (acronym: ETSICO and with reference number: CSO201782774-P), all its participating researchers and, especially, the principal investigator, Prof. Manuela Cantón Delgado, University of Seville. Many thanks go to Marie-Louise Karttunen for her always excellent editorial and anthropologically driven support. Also to Dr. Dimitri Tsintjilonis and Prof. Marcio Goldman for having read and commented upon previous versions of the paper. Finally, my immense gratitude is directed to the two anonymous reviewers of the journal, as well as its editors, Tuomas Tammisto and Matti Eräsaari.

\section{REFERENCES}

Adorno, Theodor W. 2007 [1966]. Lectures on Negative Dialectics: Fragments of a Lecture Course 1965/1966. New York and London: Continuum.

Adorno, Theodor W. 2008 [2003]. Lectures on Negative Dialectics. Cambridge: Polity Press.

Apter, Andrew 1992. Black Critics and Kings: The Hermeneutics of Power in Yoruba Society. Chicago: The University of Chicago Press.

Beckett, Samuel 1958 [1955]. Three Novels: Molloy, Malone Dies, The Unnamable. New York: Grove Press.

Beliso-De Jesús, Aisha M. 2013. Religious Cosmopolitanisms: Media, Transnational Santería, and Travel Between the United States and Cuba. American Ethnologist 40 (4): 704-720.

https://doi.org/10.1111/amet.12049.

Beliso-De Jesús, Aisha M. 2015. Electric Santería: Racial and Sexual Assemblages of Transnational Religion. New York: Columbia University Press. https://doi.org/10.7312/beli17316.

Boddy, Janice 1994. Spirit Possession Revisited: Beyond Instrumentality. Annual Review of Anthropology 23: 407-434. https://doi.org/10.1146/annurev. an.23.100194.002203.

Brown, David H. 2003. Santeria Entbroned: Art, Ritual, and Innovation in an Afro-Cuban Religion. Chicago: University of Chicago Press.

Bubandt, Nils and Rane Willerslev 2015. The Dark Side of Empathy: Mimesis, Deception, and the Magic of Alterity. Comparative Studies in Society and History 57 (1): 5-34.

https://doi.org/10.1017/S0010417514000589.

Buck-Morss, Susan 1979. The Origin of Negative Dialectics: Theodor Adorno, Walter Benjamin, and the Frankfurt Institute. New York: The Free Press.

Caillois, Roger 1984. Mimicry and Legendary Psychasthenia. October 31: 17-32.

https://doi.org/10.2307/778354. 
Comaroff, Jean and John L. Comaroff 1999. Occult Economies and the Violence of Abstraction: Notes from the South African Postcolony. American Ethnologist 26 (2): 279-303.

https://doi.org/10.1525/ae.1999.26.2.279.

Espírito Santo, Diana 2009. Making Dreams: Spirits, Vision and the Ontological Effects of Dream Knowledge in Cuban Espiritismo. Suomen Antropologi: Journal of the Finnish Anthropological Society 34 (3): 6-24.

Espírito Santo, Diana 2015. Turning Outside In: Infolded Selves in Cuban Creole Espiritismo. Ethos 43 (3): 267-285. https://doi.org/10.1111/etho.12085.

Fabian, Johanes 2001. Anthropology With an Attitude. Stanford: Stanford University Press.

Genovese, Eugene D. 1976 [1972]. Roll, Jordan, Roll: The World the Slaves Made. New York: Vintage Books.

https://doi.org/10.1215/1636545-1976-12-29.

Gilroy, Paul 1999 [1993]. The Black Atlantic: Modernity and Double Consciousness. London and New York: Verso.

Hagedorn, Katherine J. 2001. Divine Utterances: The Performance of Afro-Cuban Santeria. Washington and London: Smithsonian Institution Press.

Holbraad, Martin 2007. The Power of Powder: Multiplicity and Motion in the Divinatory Cosmology of Cuban Ifá (or Mana, Again). In Amiria Henare, Martin Holbraad and Sari Wastell (eds). Thinking Through Things: Theorising Artefacts Ethnographically. London: Routledge.

Holbraad, Martin 2019. No Sugar, Please! Tobacco Anthropology and the Merits of Contingent Conceptualisation. Anthropologica 61 (1): 5-11. https://doi.org/10.3138/anth.61.1.02.

Johnson, Paul Christopher 2011. An Atlantic Genealogy of 'Spirit Possession'. Comparative Studies in Society and History 53 (2): 393-425. https://doi.org/10.1017/S0010417511000107.

Keisalo, Marianna 2016. 'Picking People to Hate': Reversible Reversals in Stand-Up Comedy. Suomen Antropologi: Journal of the Finnish Anthropological Society 41 (4): 62-76.
Kramer, Fritz 1993. The Red Fez: Art and Spirit Possession in Africa. London: Verso.

Lambek, Michael 1989. From Disease to Discourse: Remarks on the Conceptualization of Trance and Spirit Possession. In Colleen A. Ward (ed.). Altered States of Consciousness and Mental Health: A Crosscultural Perspective. Newbury Park, CA: Sage.

Lems, Annika and Jelena Tošić 2019. Preface: Stuck in Motion? Capturing the Dialectics of Movement and Stasis in an Era of Containment. Suomen Antropologi: Journal of the Finnish Anthropological Society 44 (2): 3-19.

https://doi.org/10.30676/jfas.v44i2.77714.

Lewis, Ioan M. 2003 [1971]. Ecstatic Religion: A Study in Shamanism and Spirit Possession. London: Routledge. https://doi.org/10.4324/9780203241080.

Matory, J. Lorand 2008. Free to Be a Slave: Slavery as Metaphor in the Afro-Atlantic Religions. In Stephan Palmié (ed.). Africas of the Americas. Leiden: Brill.

McGranahan, Carole 2016. Theorizing Refusal: An Introduction. Cultural Anthropology 31 (3): 319-325. https://doi.org/10.14506/ca31.3.01.

Ortiz, Fernando 2002 [1940]. Contrapunteo Cubano del Tabaco y el Azúcar. Madrid: Cátedra/Letras Hispánicas.

Palmié, Stephan (ed.) 1997. Slave Cultures and the Cultures of Slavery. Knoxville: University of Tennessee Press.

Palmié, Stephan 2002. Wizards and Scientists: Explorations in Afro-Cuban Modernity and Tradition. Durham, NC: Duke University Press.

https://doi.org/10.1215/9780822383642.

Panagiotopoulos, Anastasios 2017. When Biographies Cross Necrographies: The Exchange of 'Affinity' in Cuba. Ethnos: Journal of Anthropology 82 (5): 946-970.

https://doi.org/10.1080/00141844.2015.1120763.

Panagiotopoulos, Anastasios 2018. Food-for-words: Sacrificial Counterpoint and Oracular Articulacy in Cuba. HAU: Journal of Ethnographic Theory 8 (3): 474-487. https://doi.org/10.1086/700980. 
Panagiotopoulos, Anastasios and Diana Espírito Santo 2019. Afro-Cuban Counterpoint: Religious and Political Encompassments. Journal of Latin American and Caribbean Antbropology 24 (3): 727745. https://doi.org/10.1111/jlca.12388.

Pérez, Elizabeth 2011. Spiritist Mediumship as Historical Mediation: African-American Pasts, Black Ancestral Presence, and Afro-Cuban Religions. Journal of Religion in Africa 41: 330-365. https://doi.org/10.1163/157006611X604760.

Pillen, Alex 2017. A Space that Will Never Be Filled: Sharp Communication and the Simultaneity of Opposites. Current Anthropology 58 (6): 718-738. https://doi.org/10.1086/694760.

Placido, Barbara 2001. 'It's All to Do with Words': An Analysis of Spirit Possession in the Venezuelan Cult of Maria Lionza. Journal of the Royal Anthropological Institute 7 (2): 207-224. https://doi.org/10.1111/1467-9655.00059.

Raboteau, Albert J. 2004 [1978]. Slave Religion: The 'Invisible' Institution in the Antebellum South. Oxford: Oxford University Press.

Routon, Kenneth 2008. Conjuring the Past: Slavery and the Historical Imagination in Cuba. American Ethnologist 35 (4): 632-649.

https://doi.org/10.1111/j.1548-1425.2008.00102.x.

Scott, James C. 1990. Domination and the Arts of Resistance: Hidden Transcripts. New Haven, CT: Yale University Press.

Seremetakis, Nadia C. 1991. The Last Word: Women, Death, and Divination in Inner Mani. Chicago: University of Chicago Press.

Shaw, Rosalind 2002. Memories of the Slave Trade: Ritual and the Historical Imagination in Sierra Leone. Chicago: University of Chicago Press.

https://doi.org/10.7208/

chicago/9780226764467.001.0001.
Stoller, Paul 1995. Embodying Colonial Memories: Spirit Possession, Power and the Hauka in West Africa. New York: Routledge.

Taussig, Michael 1993. Mimesis and Alterity: A Particular History of the Senses. New York: Routledge.

Viarnés, Carrie 2007. Cultural Memory in AfroCuban Possession: Problematizing Spiritual Categories, Resurfacing 'Other' Histories. Western Folklore 66 (1/2): 127-159.

Vitebsky, Piers 2008. Loving and Forgetting: Moments of Inarticulacy in Tribal India. Journal of the Royal Anthropological Institute 14 (2): 243-261. https://doi.org/10.1111/j.1467-9655.2008.00500.x.

Willerslev, Rane 2004. Not Animal, Not Notanimal: Hunting, Imitation and Empathetic Knowledge among the Siberian Yukaghirs. Journal of the Royal Anthropological Institute 10 (3): 629-652. https://doi.org/10.1111/j.1467-9655.2004.00205.x.

Wirtz, Kristina 2014. Performing Afro-Cuba: Image, Voice, Spectacle in the Making of Race and History. Chicago: University of Chicago Press.

https://doi.org/10.7208/ chicago/9780226119199.001.0001.

Yurchak, Alexei 2008. Necro-utopia: The Politics of Indistinction and the Aesthetics of the Non-Soviet. Current Anthropology 49 (2): 199-224. https://doi.org/10.1086/526098.

ANASTASIOS PANAGIOTOPOULOS
SENIOR RESEARCHER
CENTRO EM REDE DE INVESTIGAÇÃO
EM ANTROPOLOGIA
FACULDADE DE CIÊNCIAS SOCIAIS E
HUMANAS
UNIVERSIDADE NOVA DE LISBOA
anasta4@hotmail.com

